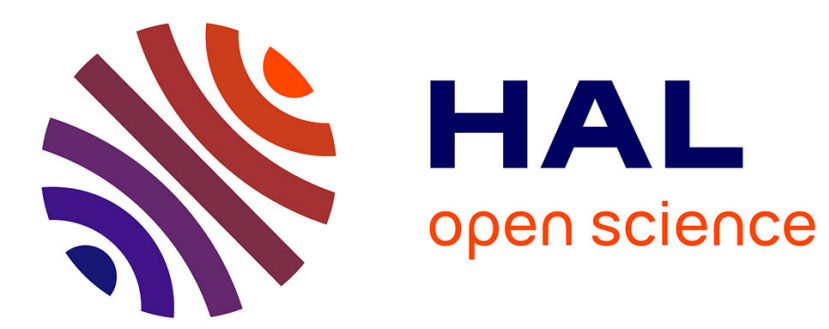

\title{
The State, Legal Rigor and the Poor: The Daily Practice of Welfare Control
}

\author{
Vincent Dubois
}

\section{To cite this version:}

Vincent Dubois. The State, Legal Rigor and the Poor: The Daily Practice of Welfare Control. 2013. halshs-00836423

\section{HAL Id: halshs-00836423 \\ https://shs.hal.science/halshs-00836423}

Preprint submitted on 21 Jun 2013

HAL is a multi-disciplinary open access archive for the deposit and dissemination of scientific research documents, whether they are published or not. The documents may come from teaching and research institutions in France or abroad, or from public or private research centers.
L'archive ouverte pluridisciplinaire HAL, est destinée au dépôt et à la diffusion de documents scientifiques de niveau recherche, publiés ou non, émanant des établissements d'enseignement et de recherche français ou étrangers, des laboratoires publics ou privés. 


\section{The State, Legal Rigor and the Poor: The Daily Practice of Welfare Control}

Social Analysis, forthcoming.

Vincent Dubois

MISHA - 5, Allée du Général Rouvillois CS 50008 F-67083 Strasbourg cedex France +33

(0)368 856170 vincent.dubois@ misha.fr

Abstract: The state comes into being through its acts. This paper focuses on state acts par excellence, by which the state controls its population. It is based on ethnographic fieldwork on the control of welfare recipients by public welfare agencies in France. I consider investigations conducted in the homes of welfare recipients as a form of bureaucratic interrogation, with particular emphasis on its defining features, modalities and uses, and how it contributes to our understanding of contemporary practices in the institutional treatment of welfare recipients. The impact of the institutional power of constraint is combined with that of the uncertainty of the recipients' situations, of the modalities of their control, and of the rules enforced on such occasions. The paradox of these checks, which are made in the name of legal rigor but characterized by uncertainty and the discretionary power of grassroots agents, reveals the broader functioning of a government of the poor, based on the combination of a multitude of individual relationships, which though unevenly coordinated derive from a structural rationale - that of the economic imperative of putting people back to work combined with a moral undertaking of reforming habituses that fail to conform to the job market's and/or the welfare institutions' demands. Rather than disaggregation of the state, individualization and uncertainty can be viewed as a consistent mode of governance in which discretion and leeway of street-level bureaucrats are necessary for the state to exert power on citizens' behaviors.

Keywords: state acts; control; welfare recipients; welfare investigators; discretion; interrogations; formal rules; France; minimum benefits. 


\section{Introduction}

\section{State acts and bureaucratic encounters}

In his paper advocating for a renewal of the anthropology of the state, Trouillot suggests a research strategy consisting in "focus[ing] on the multiple sites in which state processes and practices are recognizable through their effects" (Trouillot, 2001: 126). I share the general perspective according to which one of the main purposes of studying the state is to account for its impact on individual lives, material conditions of living, modes of social organization or representations of the world, but my starting point is slightly different. In my view, it is necessary to grasp "state processes and practices" themselves, before trying to identify such possible effects, and in order to better identify them.

Accordingly, this paper focuses on "state acts" (Bourdieu 2012) by which agents vested with the power of the state define situations, classify people, and control access to resources. State acts are inseparably symbolic and material, relying on abstract categories and on concrete objects, consisting of both discourses and bureaucratic routines, shaping the perceptions of the people exposed to these acts as well as their tangible situations. ${ }^{1}$ To be performed, such acts require institutional settings and resources accumulated in the socio-historical genesis of the state, such as legal rules, specific organizations, finance, and civil servants. Conversely, if these pre-existing conditions, which define what we call "the state", are necessary for them to be carried out, it is only through these deeds that the state "comes into being". ${ }^{2}$ State power, monopolies and images are realized, and sometimes materialized, by these very concrete acts of authorizing, sanctioning, or providing identity documents. On these occasions, citizens experience the state, which otherwise remains an abstraction to them. In other words, the

\footnotetext{
${ }^{1}$ As a result I will not take up the common distinction between 'images' and 'practices' of the state in anthropological literature discussed in the introduction to this issue.

${ }^{2}$ See the introduction to this issue.
} 
performance of its acts is the way the state, from "a fiction of the philosophers", comes to “exist in the phenomenal world", to paraphrase Radcliffe-Brown's famous phrase ${ }^{3}$.

Day to day physical encounters between state agents and citizens are a prime setting in which to observe such acts. As Trouillot puts it: "Behind the banality of these millions of encounters between individuals or groups and governments we discover the depth of governmental presence in our lives" (Trouillot, 2001: 125). Following Lipsky’s (1980) foundational theory of street-level bureaucracy, herein I argue that these everyday interactions can play a key role in the delivery of public services, in the implementation of state policy, and consequently, in the definition of what the state actually is and what it means to people involved in state encounters. Discretion is the explanatory kernel of street-level bureaucracy to account for this role. It refers to the leeway of officials in the enforcement of rules or implementation of programs. Following this notion, bureaucrats are not neutral in these processes and, under certain conditions, interpret rules and programs following their own preferences or prejudices. This can explain differences between the original conception of a policy and its actual implementation on the ground. Moreover, according to Lipsky, discretion serves as a basis for the possible "policy-making role" of street-level bureaucrats. In this paper, I bracket debates about the decline or rebirth of discretion (Evans \& Harris 2004) to focus on a case in which low-ranking bureaucrats enjoy expansive discretionary power, and to elaborate on the functions and meanings of this discretion, if not arbitrariness, as a pattern of governmentality which characterizes the contemporary neoliberal state (Foucault, 2010). Discretion is sometimes associated with clientelism or corruption, especially in non-Western states (Blundo, 2006). It is often viewed as a flaw in the bureaucratic and policy system.

\footnotetext{
${ }^{3}$ Quoted in Trouillot, 2001, 126.
} 
Conversely, I will argue that discretion can in some cases be a central element of this system and, in such cases, serve a policy orientation. ${ }^{4}$

To do so, this paper focuses on what can be regarded as the state act par excellence: control practices. More precisely, I analyze here the daily enforcement of control by street-level bureaucrats in French welfare agencies. I show that contrary to the common sense idea of control as a rote enforcement of rules by a bureaucratic machinery following a strict chain of command, local agents of control have ample room to maneuver and partially define the legal norms they are supposed to secure "on the job." My research is proof that everyday practices and interactions in relatively banal settings serve as the organizational foundation of the state and state policy (Dubois 2009; Thelen, Vetters, \& von Benda-Beckmann, introduction to this volume). My argument is twofold. First, I posit that the categories of perception and judgment defined at the top of the state apparatus and inscribed in formal rules, and those streetbureaucrats actually use in their daily practice may differ, but that they closely intertwine. Individual stereotypes and discretionary interpretations of norms do not necessarily contradict the rationales of official policy, and may also serve its goals. In other words, if "seeing like a state" means imposing schematic visions that do violence to complex situations (Scott, 1998), the state also sees through the eyes of its individual agents, who face this complexity, include their own perceptions in order to master it and, in the end, use them to enforce state categories. This inevitably leads to a diversification of the ways these categories are enforced and, to a breaking up of state power and state policy into local inter-individual arrangements. But (this is my second argument), rather than disaggregation of the state, this individualization can be viewed as a consistent mode of state governance in which discretion and leeway of street-level bureaucrats are necessary for the state to exert power over the behaviors of citizens.

From welfare changes to individual interrogations

Controlling the validity of the provision of welfare, minimum income, unemployment benefits, and the situations of the recipients of these benefits is as old as welfare itself. But the meaning and form control takes has recently changed. During the period of classical welfare in Western European countries, control was nothing more than an unimportant bureaucratic

\footnotetext{
${ }^{4}$ For instance, in the case studied by Dorondel and Popa in this issue.
} 
routine. It is however a key feature of multiple transformations of the welfare state that gained momentum in the 1980s and an increasingly important part of social and employment policies. The rise of managerial rationales, with more emphasis laid on monitoring expenses, has resulted in an increase in checks both internal (within the organizations) and external (of the recipients) aimed at detecting mistakes or cases of abuse. More prosaically, the prevalence of a financial vision of welfare means that expenses have to be cut down by all possible means - including reducing the number of benefit recipients by carrying out more stringent checks. As a rule, welfare recipients are encouraged to be more "responsible." Their cases are handled individually, as part of the promotion of an "active welfare state" that strives to put people to work. The unemployed, who are now closely "monitored," are expected to give more and more in return for the benefits they receive. With unemployment high, for the most precarious and least "employable" fractions of the lower class, these principles are applied coercively, with increasingly severe checks and penalties.

Although they have much to do with the political and media stigmatization of frauds, cheats, and the "fake unemployed," control policies are not merely an effect of circumstantial rigorist discourses: they relate to deeper transformations. Control has become an instrument of social policy, in the sense that control procedures themselves fulfill a function in achieving the goals assigned to these policies. Targeting the "bad poor" and the supposed scheming of those accused of choosing welfare over work, the reinforcement of control is part of a broader political rationale that combines paternalistic morals and neo-classical economic rationalism (Cordonnier 2000). Individualized control of the attitudes of welfare clients and of their goodwill to improve their situation is currently a policy tool, inspired by neo-classical economics notions such as the "poverty trap" model, according to which benefits recipients remain on welfare after the calculation of their interest in taking a job or not (Dubois, forthcoming). This amoral rational and technical view is nevertheless associated with 
practices reviving the pre-welfare moral categories of deservingness. Control is both one of the practical means of this post-welfare policy and a symbol of it. It is meant to have an impact on welfare recipients by saving them from "the culture of dependence" and making them "prefer employment," as official discourses put it, or at the very least by reminding them of the duties that comes with their status as useless to the world. Welfare control is a practical expression of the social expectations that weigh on these categories of the population, now seen as a necessary component of the public treatment of the poor. In that sense, analyzing welfare control provides the opportunity to account for the ways "state images" (see: introduction to this volume) are put into practice. First, welfare control relies on renewed representations promoted by the state of poverty and of deprived social groups, who are more than ever suspected of abuse and fraud. Second, control is a means to enforce bureaucratic categories, which carry state images of what constitutes a "normal" citizen and a "suitable" behavior (Wedel et. al., 2005: 37-38). Last, the implementation of welfare control policies concretizes the image of a social state, which is no longer "passive" and can prove "tough" on marginalized populations, both to assert its authority over these groups and to reinsure the adhesion of "normal" citizens who work and pay taxes to the political and socio-economic order the state reproduces.

Checks may be carried out at all stages of file processing, from verification of the first form to ordinary conversations with the reception agent, counselor, or social worker, the latter of whom procures knowledge to which the institution previously had no knowledge. Checks are frequently carried out from a distance whether traditionally, by requesting supporting documents, or as is increasingly common, through recourse to computers, which make it possible to cross-reference personal data from diverse administrative files. In this paper, I 
focus on face-to-face relationships clearly organized for purposes of control, showing how this specific form of interrogation works..$^{5}$

These individual investigations are crucial, as they serve to establish the institutional definitions of individual situations that ultimately determine how would-be recipients fare in seeking assistance. Will they receive all of the requested services? Will they be asked to reimburse the state for benefits they received but have been retroactively declared ineligible for? When fraud is discovered, will legal prosecution follow? These are the sorts of questions that the everyday decisions of welfare bureaucrats determine. But how is it possible that one person could enjoy so much seemingly unbridled freedom to interpret and enforce welfare regulations and policy? If the purpose of control in welfare programs is to ensure compliance with rules, how can the very process of enforcing control itself seem to be defined by the constant blurring and remaking of rules? How can this control in the name of playing by the rules rely on such uncontrolled practices?

The investigators' interviews with recipients are decisive because of the combination of three factors: the coercive power of welfare institutions is vested in them; this power is exerted over the uncertain situations of the recipients; because the modalities of control remain themselves uncertain. As investigators are mandated to apply rules to cases that by definition do not fit well into existing legal categories (investigations are generally launched in borderline or unstable situations), they derive their institutional necessity from these uncertainties. During these interviews, their power comes both from their institutional mandate and from the ambiguity of the situation and the unpredictability of the check's outcome. Far from mutually exclusive, the uncertainty of the situations and institutional power are intertwined and

\footnotetext{
${ }^{5}$ The approach I have chosen here leads me to not consider a number of other dimensions (such as how the institution decides to investigate a given recipient or the backgrounds and practices of the recipients who undergo those checks).
} 
mutually reinforcing. This double necessity confers a strategic role on interviews with recipients.

In this sense, welfare interviews cannot be seen merely as an enduring long-established practice of the welfare state; they are, on the opposite, very much part of its contemporary transformations. They attest to the growing role played by direct, physical encounters between welfare recipients and representatives of welfare organizations (in welfare offices, in the homes of recipients, in various appointments or summons), as the provision of benefits on the basis of the administrative recognition of a status gives way to case-by-case assessment of applicants' situations and behaviors (Dubois 2005). In this new configuration, what used to be a simple bureaucratic practice of file verification has become a key instrument of contemporary social and employment policies that, in practice, increasingly consist in a government of the poor, as they strive to remake dispositions and behaviors more so than socio-economic structures.

The paradox of a rigorist state policy dependent on ambiguous individual interactions thus yields broader insights into how such a government works. It does not revolve around a politically legitimized central authority, but rather arises from a multitude of individual relationships, which though unevenly coordinated derive from a structural rationale. ${ }^{6}$ Fragmentation does not necessarily amount to weakness or dismantlement of the state; it is in this case a specific way for the state to exert power on its population. For while interactions of control are pre-framed in and by the institutional and relational structures that precede them (Bourdieu 1990a), several conditions keep them relatively indeterminate. The control of the situation of control by the investigators constitutes both the necessary condition and the means of an institutional control whose practical basis partly escapes the institution's control.

\footnotetext{
${ }^{6}$ A similar rationale is at work in contemporary immigration policies (see Spire 2008).
} 


\section{Fieldwork}

This paper, which is part of a broader research project on the control of welfare recipients (Dubois 2003, 2006), is based on a study of how minimum benefits recipients in France are controlled by local representatives of the welfare state. ${ }^{7}$ Controls mostly focus on the Revenu Minimum d'Insertion (RMI), one of the main benefits in France paid to adults over twentyfive, and the Allocation de Parent Isolé (API), the lone parent benefit for single mothers. ${ }^{8}$ This research was conducted between 2001 and 2003 and focused on the institution responsible for distributing and controlling these benefits in France (Caisses d'Allocations Familiales, CAF - family benefit offices). ${ }^{9}$ Five sites were selected for their diverse geographic and socio-economic qualities, and across sites, I conducted forty-two interviews with investigators and thirty-nine with managers of the relevant institutions. Additionally, I conducted direct observations of checking procedures for a total of twelve weeks between June 2001 and February 2002. I followed investigators on their routes and to home checks where welfare recipients were interviewed. For methodological reasons, it was not possible to conduct interviews with recipients, which might have otherwise shed more light on perceptions and response to control. While I observed the attitudes and reactions of recipients during checks, because this paper focuses on the practices of investigators, I will not address the viewpoint of recipients.

\footnotetext{
${ }^{7}$ A previous version of this paper has been published in French in Actes de la recherche en sciences sociales, 178, 2009, p. 28-49. It has been entirely revised for the purpose of this issue.

${ }^{8}$ RMI and API merged into a more workfare-oriented benefit (Revenu de Solidarité Active, RSA), in 2009.

${ }^{9}$ The participation of General Councils in the control of RMI recipients as a result of the attribution of RMI provision to the departments in January 2004 will not be addressed here.
} 


\section{The Indetermination of an Institutional Injunction}

In the name of greater rigor - both in terms of severity and accuracy - control practices have become prevalent in monitoring and applying the rules pertaining to welfare provision. Yet, these practices themselves largely escape the strict legal and institutional framework they are meant to guarantee by implementing and enforcing rules against welfare recipients.

\section{The stringency of vague rules}

However precise and thorough they may be, the application of legal regulations always entails a degree of uncertainty and leeway or appreciation for those in charge of enforcing them, even if they are at the bottom of the bureaucratic ladder (Bourdieu 1990b; Lipsky 1980). In the administration of social welfare in contemporary France, low-level bureaucrats have come to wield considerable power in governing members of the lower class. Less so than interpreting rules in light of novel situations, these grassroots workers tend to translate their interpretations of situations into the language of rules. Because recent reforms to social policy favor benefits dependent on family and socio-professional situations over social rights granted on the basis of a status, these reforms have significantly changed the use of law in bureaucratic work. The latter is no longer only about ensuring the conformity of a file - met with a degree of appreciation - but, as the administrative jargon aptly puts it, about “establishing the situation" - i.e., exerting what Pierre Bourdieu (1991) calls a power of nomination. This marks an important change in control practices: the verification of objective criteria (such as flat size, number of dependents, professional status, etc.) has given way to detailed evaluations of lifestyles and living conditions as regulations now require applicants and recipients to be assessed in terms of individual situations.

As a result, grassroots agents have an unprecedented amount of leeway, especially as their tasks of legal characterization are based on frequently vague criteria. The paradigmatic 
example of this is the concept of being "isolated" (or "single"). Being isolated is a precondition for single parent means-tested benefits and factors into calculations of other benefits. The notion of isolation is largely intangible and a frequent source of suspicion for welfare agents and for the general public as well. It features prominently in the control of welfare recipients. Neither jurisprudence nor the ongoing process of formalization of criteria within welfare organizations have erased uncertainties regarding the definition of isolation and, conversely, marital life. ${ }^{10}$ The application of these categories still hinges on the statements and performances of recipients in interviews, which are subsequently validated or invalidated by investigators based on a number of different clues they use to "get an idea of the situation," as they say, and which they ultimately assess in light of regulations. Additionally, the practical conditions of the investigators' work limit the impact of prescriptions from the hierarchy and favor discretionary power. ${ }^{11}$ Until recently, investigators only received on the job training from a senior colleague and mostly learned through individual experience. Only the most recently appointed investigators have received institutional training before taking up their duties. Yet, as we discovered, these training sessions are less aimed at ensuring inculcation of institutionally defined norms and more aimed at exposing trainees to a wide range of practices. Institutional norms have little binding power anyway: they are enunciated in the charter of control issued in 1998, which reasserted a number of principles while making few precise prescriptions. ${ }^{12}$ Compliance with the charter is

10 'Marital life' is the bureaucratic category for recognized couples who are not officially married.

${ }^{11}$ For a sociological use of this concept, see Spire 2005. For a discussion of the evolution of discretion in welfare administration, see Evans and Harris 2004.

${ }^{12}$ This Charter was followed by a circular, about which similar remarks can be made. "Cadre juridique du métier d'agent de contrôle", Circulaire CNAF nº 2001-135 du 26 juin 2001. 
left up to the investigator, who may also take into account local norms and expectations. For instance, during our observations, the obligation of warning recipients ahead of a home visit was unequally respected, even recognizing (or not) this obligation significantly impacts the manner in which control is achieved, be it, in the investigators' words, "assessing the situation" of recipients and letting them prepare for it to "tracking down cheats" by taking them by surprise.

Investigators view their situation as both a blessing and a curse. Their administrative work is made more interesting by their independence, but they describe themselves as left on their own. They sometimes work alone, and only the biggest offices group investigators into teams. Direct, day-to-day supervision is rare, and the office is not necessarily the primary space of work, as investigators frequently visit various organizations and go on home visits. Some investigators even process files and draw up reports from their own homes. Investigators can keep in contact with the institution through e-mail or an actual mailbox where they receive files and leave reports. This physical distance creates practical conditions that favor independent judgment: in theory, investigators are subject to the mandates of the institution, but in practice, the institution exerts little control over investigators. As one investigator explained, "In this job, you can be quite individualistic. We've got the directives, and then the managers give us pointers, but otherwise, we pretty much do what we want."13

${ }^{13}$ Investigator, woman, born in 1942, divorced, one child, father teacher and stay-at-home mother (large family), Baccalauréat holder. Joined the CAF in 1963 as file clerk, then technician (the techniciens liquidateurs key and codify the information used to manage the files and benefits of the recipients). She trained internally to become a manager but eventually became an investigator in 1977, and has remained in that position since. NB: I give the main characteristics of the investigators quoted or described in this paper, since their characteristics 


\section{Deciding the Undecidable}

The characteristics of the populations and of the social contexts subject to control further reinforce the importance of the inspectors' appreciation, as we will see now. While the rules they enforce are vague, the situations to which they apply these rules are for the most part unstable. ${ }^{14}$ Indeed, individuals whose living situations are rapidly changing or otherwise unstable are subject to greater levels of scrutiny than others. Investigators meet few recipient families with stable career, family, and housing situations. Instead, investigators concentrate their efforts on unstable relationships, changing family configurations, intermittent professional activities, and frequent moves. As intermediaries between an institution that needs fixed criteria to work and the unstable lifestyles of the populations they investigate, the investigators are well aware that the truth that is up to them to tell can only be temporary, and constitutes a compromise between their diagnosis of the situation and the need to comply with the demands of administrative processing.

You see, we tell them that accommodation is necessarily temporary and that after two months, we consider that they are living maritally. But for them, marital life can last one month or two! One day, they're with someone, and the next day it's over! Why would they want to come in and report: 'Oh, by the way, I'm living with someone now' since they might break it off the next day? ${ }^{15}$

have an impact on their practices and discourses. However, due to reasons of space, I will not be able to elaborate on this impact.

${ }^{14}$ On the translation of complex life circumstances into persuasive cases framed in terms of appropriate legal definitions, see Forbess and James on the work of legal advisers in the British welfare state (in this issue).

15 Informal conversation. Investigator since 1978, woman, born in 1950, father railway employee, mother no occupation, divorced, two children. Baccalauréat holder. Joined the 
In addition to being unstable, situations subject to control are by definition equivocal. As one investigator explained, "If everything were all black or white, we wouldn't need to go and do checks!" Although inspectees can be chosen at random from a pool of recipients where a risk has been identified as part of a so-called "targeted control" policy, home investigations can also be initiated after a front desk interaction, after suspicion has been aroused by a submitted report or letter of denunciation, and, more broadly, in situations that are too complex to be assessed merely on the basis of documents. Hence, control focuses on situations that escape the standardized application of bureaucratic categories and actually demands the application of principles of judgment that go beyond these categories. A manager in charge of the benefits department (the main department in CAF offices) explained the functional character of the inspectors' autonomy in the following terms:

The fact that the investigator is isolated from the institution has a very positive effect. It allows them to gain perspective on the internal jargon. They're not experts, they're not knee-deep in their papers, their codes, their computers; so they can act as mediators with the recipients, which is very important. They're translators. Stepping outside or beyond the rules in order to better enforce the rules: such is one of the paradoxes of control. Tenuous and non-formalized factors such as the tidiness of the recipient's homes, their clothes, or their tone of voice are taken into account. An individual investigators personal history of cases comes to serve as a sort of individual jurisprudence, with no basis other than personal experience. Investigators frequently and visibly refer to other principles than the legal rules because cases that bureaucratic categories cannot capture also do not fit the social norms on which these rues are based. The recipients' distance from the institution's norms and expectations (individuals lost in paperwork, incapable of or

CAF in 1968 as a technical agent, became an investigator ten years later after having trained for a manager position. 
unwilling to cooperate, in structurally indeterminate social situations) comes with a social distance that separates them from the investigators, as these social agents have a vision of the social world that they have forged outside of bureaucratic categories. Investigators apply this vision at the same time that they apply bureaucratic rules. This double distance makes the interaction between investigators and recipients decisive, as the latter must try their best to fit the institutional categories through a wide range of practical and cognitive resources mobilized by the investigators.

\section{Profession: Investigator}

Until 1960, inspections were conducted when employer contributions were made. Some of the agents in charge of these checks then joined the newly created URSSAF (Organization for the Payment of Employee and Employer Social Security Contributions). At that time, agents were specifically assigned the task of controlling recipients. At the time of our study, there were around 560 investigators employed in 125 CAF offices, a figure that had been stable for several years. The status of investigators is not unlike that of managers. Their responsibilities and salary range are comparable to those of social workers (though their pay is capped, which partly led to the creation of the Union nationale des agents des corps extérieurs de représentants et de contrôle de la sécurité sociale (UNACERC) in 1994). The investigators' social backgrounds are close to those of clerks, especially the technical advisors (techniciens-conseil) who are the most prevalent professional group in welfare organizations. Virtually all of the investigators in our sample were from working class or lower middle class origins. More than half had fathers who were blue-collar workers, or supervisors or engineers in the industrial sector. Around $40 \%$ had mothers who did not work, and most of those who had worked served as administrative staff, cleaners, farmers or in other unskilled roles (i.e., cashiers). Yet, investigators differed from clerks in three ways. As a group, they are slightly older (46 years old) and have worked in the benefit office longer (23 years on average, which is 5 years longer than the average for other positions); $57 \%$ of investigators are older than 50 (Statistiques de la Caisse nationale des allocations familiales 2001). Whereas for other roles in the office, the gender distribution is skewed ( $80 \%$ women, $20 \%$ men), amongst investigators, men are more represented (around 50\%). Lastly, compared to their peers from the same generations, investigators are more educated. All of the investigators in our sample held Baccalauréat degrees. Two thirds of these investigators did not pursue further education after obtaining their degree, while $20 \%$ began but did not finish law school. One third of investigators acquired degrees beyond the Baccalauréat, mostly in literature or law. A handful of investigators 
had obtained vocational degrees, and two held master's degrees. In comparison to their socio-economic and generational peers, investigators were more highly educated. The typical trajectory for an investigator involves overall upward social mobility punctuated by at least two likely setbacks. First, because most of the people who become investigators need to make a living quickly, they are not positioned well to fully take advantage of social meritocracy. Instead, they frequently take low-level but safe administrative positions after encountering difficulties in completing further studies (Gollac 2005). Second, some investigators who hoped to become managers are pushed out by more qualified peers.

These conditions create a very distinctive relationship to law that we might sum up as follows: the investigators hold a position that predisposes them to a legal formalism that they cannot uphold in their professional practices, which vary with the different relationships investigators take on with the institution that employs them. This relationship to law can be analyzed as a form of legal insecurity. Legal insecurity here refers not to legal loopholes or contradictions in existing law but rather is inspired by and extends William Labov's concept of linguistic insecurity (Labov 1976). Linguistic insecurity refers to situations in which agents who, due to their social position and trajectory (members of the lower middle class having recently experienced upward social mobility and increasingly confronted with the upper classes), have a strong faith in linguistic standards (linguistic hypersensitivity) but find it impossible to fully live up to them. The linguistic imperfections observed during their interactions with those who embody these standards are a painful reminder of the inadequacies of their efforts to be hypercorrect. Likewise, investigators are predisposed to have a strong faith in legal standards. This relates mostly to their place within the institution and more broadly to the fact that their relationships with other categories of agents (from the benefits office and other institutions, as well as the recipients they investigate) lead them to define their function in terms of a formalist conception of law. In a relational approach, I call positional legalism this formalist conception of the law based on the position of the agents in those relationships. This positional legalism pushes investigators to condemn the slightest 
deviations from the rules (hypersensitivity) and to enforce them strictly. Yet, this tendency toward legal hypercorrection and ideals of legal perfection comes up against a number of obstacles: the limitations of essential practical legal definitions, the complexity of and frequent changes to the rules being enforced, and the very nature of the social situations investigated.

Investigators respond to legal insecurity in different ways. Here, I introduce the two main types of variation that explain these different responses. The first pertains to the different relationships of the investigators to the institutions, which vary according to their career rationales. ${ }^{16}$ Some investigators are promoted as a boost at the end of a long career in the benefits office. Others have taught themselves the job and worked as investigators for a long time but now feel stuck and disillusioned. Still others are recent graduates who will only temporarily work as investigators before transitioning to a more prestigious position. Finally, there are mid-level employees who have become investigators mainly because they were unable to secure positions as managers. Each type takes on a different role and relationship with the institution. Both the "oblates" that owe everything to the institution and the newcomers whose beliefs have yet to be shaken may be predisposed to legal hypercorrection, regardless of what it takes to achieve it. ${ }^{17}$ But the déclassés who see themselves as legally

${ }^{16}$ In the sense of a succession of objective positions and of a succession of points of view on these positions, defined for instance by Everett C. Hughes (1996).

17 "Oblate" was a term in the Catholic Church referring to children recruited for the priesthood. Bourdieu used the term to refer more generally to an individual experiencing upward social mobility thanks to an institution (the Church, a school, or a public administration), and subsequently feeling grateful and indebted towards this institution (Bourdieu 1996). Ridzi (2009) and Schram et al. (forthcoming) use this notion to describe the attitudes of some welfare workers, as I do in this paper. 
competent enough to favor the spirit over the letter of the law and the old investigators often described by their colleagues as solitary cowboys who, having "seen it all," assert the supremacy of their knowledge of the field over the technical stickling that goes on in the offices, allow themselves, and sometimes indeed assert their prerogative to make a few arrangements with the rules. The latter attitudes are the most frequently observed, as are the career rationales that generate them.

The second type of variation has to do with the degree of social distance separating investigators from the populations they investigate. Some investigators are more inclined to an understanding of these as "poor people who do what they can to get by," to use one of their common phrases. Others are more motivated to seek out and punish frauds who "take advantage of the system at the expense of others," to use another of these common phrases. Here again, I will merely mention a few factors that may lead investigators to tilt either way. When directly faced with great poverty and social tragedies, agents adopt attitudes that vary according to their personal preferences (including religious and political ones) and past employment situations (for instance, having been personally unemployed or having seen relatives or close friends in that situation). Most investigators to some degree vacillate between these two poles. However, neither the frequent assertion of rigor as a value ("I like what's straight") nor the fact most investigators have not experienced unemployment or precariousness prime investigators to favor empathy for the situations and unemployment of the people they investigate.

Ultimately, the uncertainty that characterizes control practices cannot be accounted for by imprecise regulations or problems with administrative organization, even though they are factors. More fundamentally, uncertainty stems from the singular situations that investigators investigate, which frequently do not neatly fit within bureaucratic criteria, which are themselves vague. As a result, investigators may summon personal feelings or prejudices as 
well as common-sense notions of social life to produce a definition of these situations that meets the demands of rigorous institutional treatment, as my research reveals.

\section{Controlling the Situation}

Investigators usually prepare ahead of home visits. Usually, they have thorough knowledge of the welfare recipient's file. They frequently expand their knowledge of an individual recipient by speaking with neighbors, tax authorities, social workers, or gendarmerie. More broadly, these face-to-face encounters are pre-framed by thinking habits acquired through personal and professional experience. These habits inform the investigation and the investigator's conduct in interviews, with scattered elements from past experience serving as reference points within an ongoing interview. Investigators draw on knowledge of prior, similar cases, a familiar family name, the neighborhood, and other factors in a process of "typification" (Schütz 1987) that fluctuates between the unconscious activation of pre-existing schemes of perception and the methodical application of an investigative template designed to systematically record anything that might serve as a clue. Yet, though the interview is to some extent structured on the basis of the script established during these preliminary phases, it remains an unpredictable process, one that requires the investigator to make an effort to keep the situation under control.

Therefore, the first step in controlling recipients lies in controlling the investigation itself. Keeping the situation under control can be difficult because of the underlying tension of such face-to-face encounters. This is not a routine interaction for recipients, who frequently become stressed, worn out, or react aggressively depending on the perceived intrusiveness of the interview, the threat it presents to "moral identity" (Dulong and Marandin 2001), or their concerns about the outcome of the investigation (cancelled benefits, obligation to repay, prosecution). While in police interrogations and interactions transpiring within the benefits office itself, institutional representatives can rely on the perceptible features of the official 
space (desk lamps, designated queuing areas, access to paper and digital files) and assistance from colleagues in navigating the situation (Dubois 2010), the investigator paying a home visit is alone in the recipient's home, which entails risk, disruptions (a TV blaring or child crying), and even attempts from recipients to sidetrack investigations by acting, forcing the investigator to wait, or trying to seduce him or her. ${ }^{18}$

\section{Getting off to a good start}

The practical skills of the investigator are therefore particularly important, especially in the initial phases of the interaction (Gumperz 1989). This means primarily maintaining a sense of ambiguity regarding the purpose and the status of this visit, especially considering it has not been announced - uncertainty combined with surprise. Agents comply even less with official recommendations about the way they should introduce themselves to recipients than with the obligation of announcing their visits. Investigators almost never show their professional ID and rarely mention their status, merely announcing, "Mr. X from the CAF is here."

Likewise, visits are frequently justified in terms that conceal their investigative dimension: investigators are likely to give vague explanations for their visits like "I'm coming for your file," or "We need to assess changes in the situation." When recipients force investigators to be forthright with the purpose of their visit, investigators strive to depict the investigation as routine and wholly benign, omitting that the recipient has been specifically flagged for investigation. They introduce the investigation as a legal obligation, saying that welfare institutions must "ensure that the files are accurate," which leads them to be able to control "any recipient at any time." Maintaining ambiguity is both about tact (not upsetting the recipient) and tactics (encouraging him to speak freely, without arousing suspicion). This is how investigators explain it:

\footnotetext{
${ }^{18}$ Cases of physical assault are rare, though on one occasion we witnessed a recipient slashing the investigator's tires.
} 
Dubois: Do you state the purpose of your visits?

Investigator: No, we do global checks. We get an overview of the entire situation. The way I put it is that at the CAF, we work mostly on the basis of statements. For instance, I tell them, "You see, on the income statements, we take into account the income that you fill in. We don't ask for proof, pay slips, things like that. So it's perfectly normal that once in a while we'll check a situation. If your situation fits what's in your file, everything will go well. On the other hand, if there are discrepancies, then we'll rectify your file." But I don't say precisely why I'm coming. ${ }^{19}$

When they ask why we're there, I tell them. Well, I don't tell them the actual motive right away, but I say we're there to check the files, that the CAF has an obligation to check on the recipients, and that this time it just happened to be them. And only then do I get to the heavier stuff. ${ }^{20}$

Another technique consists in having recipients furnish official papers and especially identification. While identity checks may have police undertones, dealing with documents can also have a neutralizing effect, as the first instants of the relationships are fixated on an object and direct confrontation is delayed. Some investigators thus systematically ask for confirmation of the information mentioned on the papers, initiating an exchange that consists in a form of cooperative back and forth dialogue. This is for instance the case with the family register (livret de famille), "a non-conflictual document, [which] makes it possible to see who

\footnotetext{
${ }^{19}$ Investigator since 1981, woman, born in 1942, two children, married to a (retired) manager in the industrial sector, father truck driver, mother child-minder.

${ }^{20}$ Investigator since 1998, man, around 40 years old, single, father blue-collar worker, mother CAF technical advisor, studied English and law, became a CAF file clerk after having failed an exam to become a police inspector.
} 
people are, how many children they have, the marriage, check for possible spelling mistakes." 21

\section{Keeping the upper hand}

In contrast with in-office visits voluntarily initiated by clients, home visits are initiated and led by investigators. In this specific case, "despite the appearances of equality, reciprocity and cordiality, the participants' roles, i.e., the right to speak and the obligation to answer, are predetermined, or at least subject to strong constraint" (Gumperz 1989). The investigator asks questions and leads the interaction, while the recipient merely reacts. The interaction is structured by a questionnaire, often materializing in a small sheet with a number of sections to be completed (family situation, professional situation, etc.). Investigators use such documents as mnemonic aids, as a pretext for repeating questions, and as a means of reorienting the interview. Some inspectors only take notes in a notebook. In such cases, the questionnaire is internalized, and it guides the interview in a way that is invisible to the subject of investigation. Sometimes this is done on purpose, in order to disorient the recipient or at least to lower his or her vigilance. Indeed, one inspector we talked to had been nicknamed "Columbo" by his colleagues for his superior command of such tactics. As he explained: My working method is quite a personal one. That is, I give the recipient the impression that I'm going all over the place. But actually, my interview's pre-planned. So I kind of go all over the place on his situation, his job, and then I say "Oh, I forgot this.” But actually, I'm trying to throw him or her off. Or otherwise I close my briefcase, I pretend like I'm leaving and then I come back to ask a question that I say I'd forgotten about, but that was actually on my mind since the beginning. The thing is, I try to throw them off a bit because some of them are prepared. We've already got three investigations in

\footnotetext{
${ }^{21}$ Informal conversation during a round of checks; investigator, woman, around 50 years old.
} 
the file, so they know how it works by heart. I sort of try... to destabilize them because some of them have readymade sentences and they've been briefed by a social worker. ${ }^{22}$ Bluffing and dissimulation, which are part of any interrogation, particularly matter here. ${ }^{23}$ Investigators frequently allow themselves to tell small lies in order to uncover recipients' lies, exaggerate the consequences of false statements, and ask for information they already have as a test of goodwill. More broadly, investigators retain control of the game by controlling themselves. As Alain Bancaud notes about magistrates, controlling oneself makes it possible to control those who cannot do so (Bancaud 1993). Investigators must therefore never show weakness, and they constantly monitor their own behavior: self-control is a condition of control.

I find this job difficult because you always have to be careful about what you say, the way you behave .... You have to have a special kind of tact. [...] You have to be quite strong mentally .... You can't be too anxious, you can't do this job if you're afraid while you're doing it, and you never know what you're going to find. I've been held against my will once, lots of things happen in this job, so you shouldn't be scared! ${ }^{24}$ The relation between self-control and control becomes particularly clear in cases where the recipients' aggressive attitudes or strategies to arouse pity threaten the investigator's control of his or her own attitude. Investigators can empathize with the suffering they witness. One

\footnotetext{
${ }^{22}$ Investigator since 1997, man, born in 1967, single (recently separated from an investigator), father diesel mechanic in the railway company, mother CAF itinerant reception agent CAF. Holder of a master's in business law. Joined the CAF in 1992 as litigation editor.

${ }^{23}$ Research on police interrogation in the USA has shown that the process is a "confidence game based on the manipulation and betrayal of trust" (Leo 1996: 259; see also, Leo 1994).

${ }^{24}$ Investigator since 1998, man, around 40 years old, single, father blue-collar worker, mother CAF technical advisor
} 
investigator told us that he sometimes felt pity for inspectees, even giving some recipients restaurant vouchers. But, he explained, it was easier to give vouchers to older women than younger women, because younger women might take such actions the wrong way. Yet investigators claim that they do not let themselves pity recipients for their suffering. They resist such feelings because the job requires it. As one investigator explained, you can't last as an investigator if you allow yourself to be too sensitive.

Investigator: Some of them tell me [she adopts a whiny tone] "Ooh, I'm ill..." So they undress, they show me their scars. So I tell them nicely, "No, no, put your clothes back on. I'm not a doctor." When they say they're ill, they hope they'll be asked fewer questions, for fewer documents. Some of them go, “Oh, I don't know where my head is, you understand, you can't ask me too much, I've been ill," or "I've got cancer." I dread that enormously. Each time I tell them, "Listen, I'm very sorry about that, but..."

Dubois: Do you sometimes give in to your feelings, though?

Investigator: You can’t let yourself be moved, because if I start letting people move me, then all that's left for me to do is to throw myself into the sea when I leave work. You can't carry the weight of the world. I mean, we've all got a family; we've already got problems with the family, the parents. I tell myself, I can't take on the recipients. So, it's not that I'm particularly tough, but I listen, it comes in and it goes out. Otherwise you can't do this job, it's impossible. If you started feeling sorry for everyone, I guarantee you that you would shoot yourself in the head at the end of the day. $^{25}$

\footnotetext{
${ }^{25}$ Investigator since 1997, woman, born in 1952, father sailor, mother city hall employee, married to a craftsman, two children. Joined the CAF in 1974, as a technician and then as a reception agent.
} 
Investigators also resist feeling sorry for recipients because they're all too aware that recipients oftentimes intentionally and manipulatively try to inspire such feelings. Suspicion works as an antidote to uncontrolled compassion. One investigator described what happened in an investigation where the recipient "went on and on about her problems":

By the end, she was playing the pity card. If I'd followed her there she would have started crying. She's not sure of herself, so in case she'd revealed something that wasn't to her advantage, she played the pity card for my benefit. ${ }^{26}$ Lastly, legalism and formalism also serve to counteract strategies aimed at arousing pity by desensitizing investigators to the recipients' suffering: both are resources that give meaning and justification to their practices by preventing them from "letting their feelings take over," as one investigator explained:

I could say it doesn't affect me, but it actually does. You've got people telling you things like, "You don't care, you're a civil servant, you get paid at the end of the month.” That happens often. You shouldn't let it eat you up, either. It doesn't do much good. You shouldn't think about it in the evening, because it kind of gets to you. Once it's been said, that's it. There are people who have reached the end of their rope, they've had enough. But I try to stay technical, full stop. I tell them it's the law and, "If you're not happy, go and see your MP and ask them to change the law," and that's it. ${ }^{27}$

\footnotetext{
${ }^{26}$ Investigator since 1987 , woman, born in 1955, father technician in the public sector, stayat-home mother. Married to an executive of a public company in the business sector, three children. Baccalauréat holder, joined the CAF in 1975 as file clerk.

27 Investigator since 1981, man, born in 1946, father gendarme, mother no occupation, married (to a social security manager), one child. Dropped out before completing a bachelor's in law, joined the CAF in 1977 after several years working on and off in various unskilled jobs.
} 
Another one also reckoned:

They say they can't make it, they've been left behind, or their ex-partner's mean, or that so and so...well, any old excuse, I'd say. We tell them that anyway, the law applies to everyone, full stop. We enforce it on them, as we do on others.... You have to explain that it's the same for everyone. There are other people out there who are alone and jobless. It's no reason, we know, but that's the way it is, there's not much we can do about it, we have to enforce the law. ${ }^{28}$

\section{The Uses of Interrogation}

Controlling the interview situation is so important because the interview itself plays a central role in the control of welfare recipients. This is in part because of the so-called declarative system of benefit provision, which is (at least theoretically) based on statements provided by recipients, and particularly because of the sharing of the burden of proof it entails. Recipients must be able to prove that the facts match their statements, but in the event of discrepancies, the institution must also prove that the situation on the statement is not the real situation. The interview is thus doubly important, first because possible contradictions between the recipients' initial statements and the version they give to the investigator can be a way of exposing them, and secondly because new statements made during the interview (about "resuming marital life," for instance) may effectively put an end to the investigation process. As in police investigations, a confession remains the best evidence (Proteau 2009). Beyond

\footnotetext{
${ }^{28}$ Investigator, woman, born in 1952, father craftsman in the construction sector, stay-athome mother. Divorced, in a common-law union (with a URSSAF director), two children. Holder of a bachelor's in Italian, joined the CAF in 1980, worked as technician then manager, gave up that post for family reasons and became an investigator.
} 
the imperative of solving the case, the interview is also said to have a pedagogic value. Practices that alternate between sanctioning and advising, threatening and informing are supposed to enable prevention of fraud or errors. These practices are also supposed to help redressing the recipients' behaviors, at least those relevant to the administration's activity: making sure they provide information in case of a change of situation or update their file. From an instrument of bureaucratic control, the interview thus turns into an instrument of social control.

\section{Obtaining a confession}

The relationship of control is first and foremost about obtaining the information necessary to rule on a situation. We have seen that investigators use diversion tactics to reduce suspicion and encourage recipients to collaborate as fully as possible. ${ }^{29}$ This is what an investigator explained:

I always try to be very easygoing. I always shake people's hands, they like that. It makes them feel at ease. I always find a subject to lighten the mood at first. For instance, if there are kids, I talk about the kids - "He's cute. He's tall for his age" - stuff like that. If there's a dog I talk about the dog, if there are houseplants I talk about the houseplants... That way the person will feel more at ease, less guarded. So that during the interview they'll be less vigilant. That way I get much more information out of them... If you start out all police-like, the person will be on guard: either they'll get angry and the interview's not going to go well, or they'll withhold information. That said, I go all the way: I ask for the necessary papers; I repeat the same questions; I

\footnotetext{
${ }^{29}$ On the tactical use of framing ambiguities, see Goffman 1974.
} 
consult....I used to be more direct, more like a cop at first. I've found that you get more by being calm, serene. ${ }^{30}$

In order to rule on a situation, investigators rely on documents and statements, but also, crucially, on the confrontation between documents and statements. Documents are useful not only for the information they directly provide but as reference points to steer the interview, reorient the investigation, and drive the recipient into a corner. Recipients, who have negative symbolic capital, must then struggle to validate their statements (Pinto 1984). As this validation generally cannot be made in due form with documentary evidence, they must resort to the expression of a goodwill both administrative (taking the required steps) and social (making efforts to get by), which is usually ultimately in vain because it is based on nothing else than their word, which is precisely the source of suspicion.

Due to the way evidence is constituted and the importance of criteria that do not rely on tangible material facts, the primary objective of many investigations is the collection of statements from recipients in which they confess to having previously made statements without the ability to back them up with evidence. Investigators stand to benefit from getting recipients to confess to living in couple, finding employment, or having unreported income. Getting someone to confess is a way to fill the gap between their personal conviction and the formal justification of this conviction they can provide. Through discussion and exchange, recipients are led to provide missing evidence to the investigator. When this happens, the control then becomes a regularization with the recipient's willing or unwilling help. A written and signed statement matching the investigator's expectations is a key element that makes collecting additional evidence superfluous. Signed statements allow investigators to terminate the investigation with neither lingering legal ambiguities nor the need for further investigative

\footnotetext{
${ }^{30}$ Woman, born in 1942, two children, married to a (retired) industry executive, father truck driver, mother child-minder, investigator since 1981.
} 
steps. "It's the icing on the cake," as one investigator told us. This explains why interviews with recipients can work as interrogations, aimed at obtaining confessions; the investigators themselves refer to the model of police interrogation, albeit sometimes humorously or in order to distance themselves from it.

Chit-chatting in order to relieve tension and dull a recipient's awareness so that he or she will "slip up" as investigators say; asking questions in a roundabout manner ("How do you manage with so little?"); prompting contradictory statements by repeating the same question in different ways; preaching lies to get to the truth ("You've been a lone mother for two years, haven't you?"; making seemingly unrelated enquiries in order not to awake suspicion; testing the respondent's good faith by asking them for information that is already known: these are a few of the investigator's skills.

\section{Producing an acceptable version}

Once the relevant pieces of information have been collected, the investigator must order and explain the facts in accordance with their own opinion of the situation, the law, and administrative rules, and only secondarily in accordance with the recipient's beliefs and desires (lest the recipient appeal the investigation).

Producing an acceptable version means presenting a coherent set of established facts that cannot be contradicted by tenuous elements that make uncertainty remain. Like the jurors examined by Garfinkel (1984), for investigators "if the interpretation makes good sense, then that's what happened" (106). The plausibility and coherence of the version presented will be assessed on the basis of criteria that are external to the recipients' experience. The behaviors of recipients are explained in reference to the living standards and the model of rationality that investigators apply, that is to say in reference to social norms objectivized in administrative rules. Investigators will most likely not recognize as true the recipients' statements that their system of values leads them to judge as irrational. For instance, it is 
impossible to acknowledge the possibility of long-term free accommodation without having in mind the forms of solidarity specific to the most underprivileged classes. Judging such a situation on the basis of the middle-class standards of domestic economy, the investigators are more likely to consider it as an unreported sublet. Similarly, if an unemployed person claims not to have registered with the unemployment agency in order to receive the benefits he or she is entitled to, this recipient will likely be suspected of lying or being a clandestine worker. For investigators, few other reasonable explanations for such discrepancies would come to mind. In working to produce an acceptable investigation, investigators strive not so much to establish the truth as they do to achieve a reasonable outcome, which they judge in terms of feasibility (it's no use reporting something that cannot be proven), cost (the steps taken should be proportionate to the expected result), and pragmatism regarding the possibility of refunds (there is no point in ruling that a benefit provision is unwarranted if the recipient will obviously be unable to ever pay the money back). This very practical rationale consists not so much in doing what is legally required, but rather in doing what it is socially possible within the bounds of the law, on the basis of considerations of effectiveness and what the investigators deem to be right.

The production of this reasonable outcome can be likened to the technique of legal fiction: ruling on a situation in a way that one knows does not exactly fit the reality of things, but that is efficient and/or fair (or at least justifiable). This is particularly the case regarding the registrations of dates for events like new employment or marriage that affect benefits entitlement status. Once these events have been established, the point for the investigator is not to look for the precise date to fill in, but to come up with a solution that balances potentially conflicting goals like not unduly disadvantaging recipients, not selecting a date that may be the right one but cannot be proven, or reporting what would be considered to be a fair amount of unwarranted benefits. The following excerpt from our field notes follows an 
investigator as he questions a recipient about date of his marriage, demonstrating how investigators strive to balance such concerns:

Wednesday 2 January 2002, 9.30am. The route begins in a working-class suburb. The investigator is due to an interview with a male RMI recipient in his thirties and to check in on his living accommodations. It is possible that the man is "living maritally," and in the event that his partner has resources, the man's RMI benefits could be subject to cancellation. The man's flat is clean and rather comfortable, in contrast the rundown neighborhood it is situated in. The man recently relocated to this city. He used to live a few hundred kilometers away in a city where he managed a small Internet-related company. His company went bankrupt, and as he was not eligible for unemployment benefits, he applied for the RMI even if "it hurt, because I'd never thought I would have to ask for that." He is currently looking for a job and occasionally works part-time at a warehouse. He hurries to ushers us to the living room table and seats us. There are only two chairs, so he stands in front of us, behind the table, which makes the scene look like a trial, especially as he speaks a lot to explain and justify his situation. He is visibly tense; his voice is shaking. The investigator asks for various documents and his ID. Early in the interview, the investigator calmly asks the man about his housing situation. Immediately, the recipient answers, "Well, we're together." The definition of this statement is to become the object of the remainder of this encounter.

Man: "Cohabitation" is not a notion... We have separate accounts, we pay for things separately. I moved in because I had no place to live, but I didn't see myself... At first, for me, it was temporary. You shouldn't see this as us trying to deceive anyone. Investigator: No, if we send an investigator, it's to look into the situation, not because we think you've done something wrong. We take facts into account. So, this was temporary at first, and it became temporary in the long term... 
The investigator asks the man when he and the woman got married. After a few moments of silence, the man replies, "So that's going to be taken into account for the calculation of my RMI?"

Investigator: Yes.

Man: I find that unfair. If I'd gone to my parents, I would have been put up, fed, and I would still have received the RMI. Now it's going to be up to my girlfriend to provide for me, even though we're not married.

Investigator: Yes, but the RMI's not a long-term thing anyway. So you've been living here since when?

Man: Since September. But you know, my girlfriend makes very little. She's an administrative agent at the rectorat [education office].

Investigator: Are you registered with the ANPE [unemployment agency]?

Man: Yes.

The man hands over his registration card and his neatly ordered papers.

Investigator: And what's your part-time work agency?

Man: Manpower.

The man pulls out his pay slips.

Investigator: What about the trimesterly declaration of resources, have you sent that? And did you mention these jobs?

Man: Yeah. I put everything on there. But I find that a bit absurd. You're better off doing nothing, because if you work a little, they lower your RMI benefit.

Investigator: Staying home doing nothing is not the solution.

The investigator consults some documents and calculates the sums that have been paid out.

Man: I'm actively looking for work. These part-time jobs are one- or two-day things. It's very precarious work. I'm doing an exam for the [unemployment agency] now, 
they're going to hire. Otherwise, I applied for a job at the Chamber of Commerce. I hope there won't be any issues, since there's a check now.

Investigator: No, no, it's completely unrelated. And do you contribute to the budget? Man: Yeah, I pay for the phone bill, sometimes the groceries.

Investigator: Have you filled out the accommodation questionnaire? [A document on accommodation was sent along with the investigation notice].

Man: Yeah, but we can have a look at it.

They look at the questions one by one.

Man: "Permanent accommodation" over here, what's that? I put in temporary. Permanent, that's after how long?

Investigator: It's up to you to judge when the situation has become stable.

Man: What worries me is that if I don't get the RMI anymore, I might no longer be entitled to do training. I wouldn't want to find myself without RMI, and on top of that without being able to train.

Investigator: No, you'll still get the RMI for three months anyway.

At this point, the investigator has already decided that he will record the beginning of marital life on the day the investigation was conducted, without explicitly saying so.

Man: Am I going to need to pay money back?

Investigator: No, no. There's no false statement, there's no unwarranted benefits. They go back to looking at the questions, and discuss various points. Then, the investigator loops back to the topic that has been on his mind since the very start of the interview: when precisely this recipient began living with his partner.

Investigator: Well, we have to come to a decision on this.

Man: The law's the law. You understand why kids stay with their parents longer now, but personally I don't feel like... As in Tanguy. Have you seen the movie? 


\section{Investigator: No.}

Man: I'm not hiding anything. I'm not denying we're living maritally because that would be arguing against the obvious. But I wouldn't want this to be a purely administrative decision, without taking into account the conditions. I do understand the philosophy of the law. It's to keep people from taking advantage. But this is absurd.

Investigator: Well, listen, you moved in thinking this would be temporary, and then you stayed. Now the situation has become stable, you're living maritally, so we'll say it started today.

The man nods. The investigator mentions the possibility of a housing benefit. The recipient fills out the rest of the questionnaire, and signs to formally acknowledge today's date as the beginning of his marital life. "Tell me if I'm making spelling mistakes."

\section{Regularizing the situation}

The investigators' work, as we have seen, has a pragmatic objective rather than an ideal of truth: regularizing the files. "We're not white knights, but we set the files straight," as one investigator explained. ${ }^{31}$ Investigators must ensure that the "files make sense" and encourage recipients to declare relevant elements, demonstrating to recipients that they have everything to lose by not complying with the rules and much to gain much by being honest: making a fresh start on "healthy foundations" allows them to "avoid getting in trouble." 32 In practice, as part of their function as so-called advisors, investigators incentivize recipients setting the record straight. Incentives relate to the immediate concern of "clarifying the situation" and to

\footnotetext{
${ }^{31}$ Investigator since 1998, man, around 40 years old, single, father blue-collar worker, mother CAF technical advisor.

${ }^{32}$ These phrases are commonly used by investigators.
} 
the more distant horizon of an educational and preventive mission, with investigators aiming to remake the habits of recipients. "I tell them, 'Listen, stop that now, make the right statements relating to your situation.' So there's a whole educational side to it, you see."33 Beyond this, regularizing the files is also about regulating the lives they contain: encouraging recipients to take steps to find work, getting them to "pull themselves together" if they are deemed to be too "entitled," as investigators say. By putting paperwork in order, investigators also hope to put some order into the disrupted lives they investigate. Investigators reward the recipients who cooperate in regularizing their file. They usually spontaneously offer to file an application for cancellation of debt to the recipients they find reasonable. This is a way of encouraging goodwill and lightening the burden of the investigation for recipients deemed to be honest. This is also a way to make the situation seem less unpleasant when they make a determination that a recipient has received unwarranted benefits. This is, finally, a way to keep their conscience clean: they don't turn a blind eye, but they don't drag down the recipients further. As one investigator explained, "It gives them hope, though there really isn't much hope, and that way we can leave them alone."34 Beyond the possible material sanctions they can lead to, these home interviews with welfare recipients have a strong moral dimension. These interviews are tests of morality, not only in the sense that they aim at identifying lies and wrongdoings, but also because those who lie or cheat must acknowledge having done so. Those who confess expect leniency; those who do

33 Investigator, woman, born in 1954, father workshop foreman, mother no occupation, divorced, two children. Baccalauréat holder, studied law for one year. Joined the CAF as file clerk, then technician. Became an investigator in 1997.

${ }^{34}$ Investigator since 1987 , born in 1955 , father technician in the public sector, stay-at-home mother. Married to an executive of a public company in the business sector, three children. Baccalauréat holder, joined the CAF in 1975 as file clerk. 
not are pressured by being asked to sign a sworn statement ("I hereby swear to be living alone..."). The possibility of providing a false sworn statement comes with the implicit (even if unfounded) threat of a harsher sanction. As an institutionalized offer to recipients to "unburden their conscience" and gain "forgiveness" if they freely admit to having done wrong, the interview can be likened to a confession (Hahn 1986). It also has a moral dimension in the sense that it serves as an opportunity to point out the rules and the duties of welfare recipients. Indeed, the legal obligations of welfare recipients are quite often merely the bureaucratic translation of social expectations; legal obligations and social expectations merge constantly during investigations. Lastly, these interviews are not only about the functional imperative of regularizing the files; they are also a symbolic form of social regulation (Bourdieu 1987). They provide an opportunity to give the institutional representative information on the respondents' lifestyles, which is related to models of behavior (family structure, stability of the couple, education of the children, relationship to work, etc.) and the legitimate canons used to evaluate them.

The control of welfare recipients, which has become an instrument of subsidiary social policies, is of both an economic and a moral nature, as is clear in the way the interviews are conducted. Justified in the name of a managerial imperative of rigor in social spending, it fits more broadly within the logic of an "active welfare state" in which assistance is seen as the enemy of employment, and unemployment and social problems are seen as the responsibility of those entitled to benefits. Investigations and sanctions serve partly to cut down spending by filtering out beneficiaries, as can be observed in the case of the RMI, for instance. Investigations also serve as levers used to "make work a real option for all," as the OECD puts it, or, in other words, to force people to get back to work. And while its social effects are less perceptible, control has a very strong moral dimension. Control consists first in making 
the recipients feel guilty, both to make sure that "the privileged" who have work should not expect too much, and to remind those who don't that they can only hope for conditional assistance, and not claim rights. Control consists secondly in attempting to reform habituses that fail to conform to the job market and/or the institution's demands. For all these reasons, control is not a simple epiphenomenon, but a key instrument in the ongoing transformations of the welfare state.

Beyond welfare changes, the observation of the apparently meaningless bureaucratic routine of control proves a good viewpoint from which to elaborate on the question of "the limits of the state" (Mitchell, 1991). "This entity comes to seem something much more than the sum of the everyday activities that constitute it, appearing as a structure containing and giving order and meaning to people's lives, writes Mitchell. An analogous example is the law. Once again, one could analyze how the mundane details of the legal process, all of which are particular social practices, are so arranged as to produce the effect that 'law' exists as a sort of abstract, formal framework, superimposed above social practice. What we call the state, and think of as an intrinsic object existing apart from society, is the sum of these structural effects." (94). Moreover, we have seen that the fragmentation in the implementation of "active" social welfare policies was itself a pattern of their very structure. In the last place, I would argue that the question of the limits of the state pertains to the relationship between state categories and individual habituses. The enforcement of control is itself a means to rectify the deviant welfare recipient's habituses, according to the social norms promoted by the state (which does not mean that it always succeeds). During the everyday activities of welfare control, "the state" and state agents as individuals of flesh and blood intertwine, as bureaucratic categories do with the personal modes of perception of agents (see "The Agent's Two Bodies" in Dubois, 2010: 73-136). Confrontation between state categories and individual habituses based on other grounds; internalization of these categories; interference of personal views in the 
implementation of state bureaucratic norms: these are in my view the processes we should explore in order to rethink the question of the limits of the state.

\section{Acknowledgements}

This paper is based on research previously published in French in Actes de la recherche en sciences sociales (2009) and translated by Jean-Yves Bart. I want to thank the editors of the journal and Jean-Yves for their kind help. A previous version of this paper has benefited from the comments of the participants of the Wenner-Gren Foundation Symposium in Sintra, Portugal, and from the reading seminar organized by Didier Fassin and Joan Scott at the Institute for Advanced Study in Princeton, USA, in September and October 2012. Benjamin White and Linda Garat have made useful linguistic revisions. I also wish to thank Tatjana Thelen, Larissa Vetters, Keebet von Benda-Beckmann, the editors of this issue, and the two anonymous reviewers for their comments.

\section{References}

Bancaud, Alain. 1993. La Haute Magistrature judiciaire entre politique et sacerdoce. Paris: LGDJ.

Blundo, Giorgio. 2006. "Dealing with the Local State: The Informal Privatization of StreetLevel Bureaucracies in Senegal”, Development and Change 37 no. 4: 799-819.

Bourdieu, Pierre. 1987. "La dissolution du religieux.” P. 117-123 in Choses dites. Paris: Minuit.

_ (with Salah Bouhedja and Claire Givry). 1990a. "Un contrat sous contrainte." Actes de la recherche en sciences sociales 81-82: 34-51.

1990b. "Droit et passe-droit." Actes de la recherche en sciences sociales 81-82: 86-96. 
1991. Language \& Symbolic Power, Cambridge: Harvard University Press.

1996. State nobility, Stanford: Stanford University Press.

2012. Sur l'Etat. Cours au collège de France (1989-1992), Paris: Raisons d'agir, Seuil.

Cordonnier, Laurent. 2000. Pas de pitié pour les gueux. Paris: Raisons d'Agir.

Dubois, Vincent. 2003. Les conditions socio-politiques de la rigueur juridique. Politique de contrôle et lutte contre la fraude aux prestations sociales, Paris: CSE-CNAF (with Delphine Dulong, Luc Chambolle et François Buton).

_ 2005. "Le guichet des organismes sociaux ou l'institution des pauvres". Pp 205-218 in Les débats du travail social, ed. J. Ion. Paris: La Découverte.

2006. Le contrôle des chômeurs, Paris: GSPE- DARES, ministère du Travail

_ 2009. “Towards a Critical Policy Ethnography”, Critical Policy Studies, 3(2): 219-237.

2010. The Bureaucrat and the Poor: Encounters in French Welfare Offices. Aldershot:

Ashgate.

_ forthcoming. "The Economic Vulgate of Welfare Reform: Elements for a Socio-

Anthropological Critique”, Current Anthropology

Dulong, Renaud and Marandin, Jean-Michel. 2001. “Analyse des dimensions constitutives de l'aveu en réponse à une accusation". In L'Aveu: histoire, sociologie, philosophie, ed. R.

Dulong. Paris: PUF.

Evans, Tony and Harris, John. 2004. "Street level bureaucracy, social work and the (exaggerated) death of discretion.” British Journal of Social Work 34: 871-895.

Foucault, Michel. 2010. The Government of Self and Others: Lectures at the Collège de France 1982-1983. New York: Palgrave Macmillan.

Garfinkel, Howard. 1984. "Some rules of correct decisions that jurors respect". P. 106 in Studies in Ethnomethodology. Cambridge: Polity Press. 
Goffman, Erving. 1974. Frame Analysis: An Essay on the Organization of Experience.

Cambridge: Harvard University Press.

Gollac, Sibylle. 2005. "La fonction publique : une voie de promotion sociale pour les enfants des classes populaires ? Une exploitation de l'enquête 'emploi 2001'.” Sociétés contemporaines, dossier "Classes populaires et services publics" 58: 41-64.

Gumperz, John. 1989. Engager la conversation. Introduction à la sociolinguistique interactionnelle. Paris: Minuit.

Hahn, Alois. 1986. "Contribution à la sociologie de la confession et autres formes instutionnalisées d'aveu". Actes de la recherche en sciences sociales 62-63: 54-68.

Hughes, Everett C. 1971. The Sociological Eye. New Brunswick: Transaction Books.

Labov, William. 1964. "Hypercorrection by the Lower Middle Class as a Factor in Linguistic Change." Pp 122-142 in Sociolinguistic Patterns. Philadelphia: University of Pennsylvania Press.

Leo, Richard L. 1994. "Police interrogation and social control." Social \& Legal Studies 3: 93120.

1996. "Miranda's revenge. Police interrogation as a confidence game." Law \& Society Review 30, no. 2: 259-288.

Lipsky, Michael. 1980. Street-level Bureaucracy, New York: Russell Sage Foundation. Mitchell, Timothy. 1991. "The Limits of the State: Beyond Statist Approaches and Their Critics". American Political Science Review, 85, no. 1: 77-96.

Pinto, Louis. 1984. “'C'est moi qui te le dis'. Les modalités sociales de la certitude.” Actes de la recherche en sciences sociales 52-53: 107-108.

Proteau, Laurence. 2009. "Interrogatoire, forme élementaire de classification." Actes de la recherche en sciences sociales 178, no. 3: 4-11. 
Ridzi, Frank. 2009. Selling Welfare Reform: Work-first and the New Common Sense of Employment. New York: New York University Press.

Schram, Sanford F., et alii (fortcoming), "The Recovery Model vs. the Business Model:

Representative Bureaucracy, Cultural Competence and the Contradictions of Contemporary Welfare Reform".

Schütz, Alfred. 1987. Le Chercheur et le quotidien. Phénoménologie des sciences sociales. Paris: Méridiens Klincksieck.

Scott, James. 1998. Seeing Like a State. How certain schemes to improve the human condition have failed. New Haven: Yale University Press.

Simmel, Georg. 1965. "The Poor” Social Problems 13, no. 2: 118-140.

Spire, Alexis. 2005. Etrangers à la carte. L'administration de l'immigration en France (1945-1975). Paris: Grasset.

— 2008. Accueillir ou reconduire. Enquête sur les guichets de l'immigration. Paris:

Raisons d'Agir.

Trouillot, Michel-Rolph. 2001. "Anthropology of the State in the Age of Globalization" Current Anthropology 42 no. 1: 125-138.

Wedel, Janine R., Shore, Cris, Feldman, Gregory, Lathrop, Stacy. 2005. “Toward an Anthropology of Public Policy" Annals of the American Academy of Political and Social Sciences 600: 30-50. 